\title{
POLITYKA ABENOMIKI JAKO ODPOWIEDŹ NA PROBLEMY GOSPODARCZE JAPONII
}

Kryzys naftowy w roku 1973 oznaczał dla Japonii koniec „złotej ery” doganiania państw Zachodu po zniszczeniach II wojny światowej. Boom na rynku akcji i nieruchomości w latach 80. XX w. spowodował powstanie tzw. gospodarki bańki mydlanej, której pęknięcie w roku 1990 rozpoczęło okres długotrwałego kryzysu gospodarczego, w tym przede wszystkim zaistnienia deflacji i szybkiego wzrostu zadłużenia publicznego. Ze zjawiskami tymi państwo zmaga się do dziś. Charakterystyczna dla niego kultura zarządzania oraz niechęć decydentów do reform przedłużała okres stagnacji i niweczyła kolejne lata rozwoju, zwłaszcza w sytuacji procesu starzenia się społeczeństwa japońskiego. Nieśmiałe próby zmian na początku XXI w. i pozytywne sygnały płynące z gospodarki mogły dawać nadzieję na powrót do szybszego rozwoju państwa, jednak dwa kryzysy, jeden zewnętrzny w 2008 r., a drugi wewnętrzny w 2011 r., nałożyły się na trwającą już stagnację i wymusiły zmianę priorytetów, tym samym oddalając perspektywę powrotu Japonii do grupy liderów wzrostu gospodarczego. W tych warunkach władzę ponownie objął rządzący już w latach 2006-2007 Shinzo Abe, ogłaszając własny plan na ożywienie gospodarki.

Lider opozycyjnej Partii Liberalno-Demokratycznej opierał się na złożonym programie nazwanym od jego nazwiska abenomiką. Było to o tyle zaskakujące dla obserwatorów, że Abe ani z wykształcenia nie był ekonomista, ani nawet nie przejawiał większego zainteresowania kwestiami ekonomicznymi podczas swojej pierwszej kadencji jako premier ${ }^{1}$. Mimo to jego program spotkał się z szerokim zainteresowaniem ze strony wielu ekonomistów, w tym m.in. amerykańskich liberałów (np. profesora ekonomii na Uniwersytecie Princeton Paula Krugmana) oraz tych szukających innych sposobów wyjścia z kryzysu dla gospodarek narodowych niz popularna po roku 2009 w Europie polityka zaciskania pasa (ang. austerity) ${ }^{2}$. Jednak konserwatywne, a czasami wręcz nacjonalistyczne aspekty programu Abego (dotyczące przede wszystkim chęci odejścia od narzuconego po II wojnie światowej

ORCID: 0000-0002-9996-0364, DOI: 10.4467/23538724GS.21.008.14840

1 S. Lechevalier, B. Monfort, Abenomics: Has it worked? Will it fail?, 13.12.2016, s. 5, https:// halshs.archives-ouvertes.fr/halshs-01415428 (dostęp: 21.03.2020).

2 Ibidem, s. 5-6. 
pacyfistycznego ustroju państwa) mogły odbić się negatywnie na jego planie gospodarczym, głównie w aspekcie pogorszenia relacji z Chinami i Koreą Południową. Państwo Srodka było wówczas jednym z najważniejszych partnerów handlowych Japonii, tworząc w 2007 r. trzecią największą tego typu relację na świecie ${ }^{3}$. Priorytetem miały się za to stać relacje ze Stanami Zjednoczonymi oraz Unią Europejską ${ }^{4}$. Zabiegi te były jednymi z wielu środków mających na celu powrót Tokio do pierwszej ligi, a więc odzyskanie rangi utraconej w efekcie długotrwałej stagnacji. Najważniejszym elementem tego planu była jednak abenomika, której ewentualny sukces miał nieść za sobą nie tylko korzyści gospodarcze, lecz także polityczne dla kraju od wielu już lat pogrążonego w marazmie. W związku z tym oczekiwania wobec programu premiera Abego były bardzo wysokie.

\section{Założenia teoretyczne abenomiki}

Założenia abenomiki wywodzą się z tzw. teorii reflacjonistycznych (ang. reflationism ${ }^{5}$ ), które pojawiły się po raz pierwszy w artykule Paula Krugmana z 1998 r. poświęconym problemom gospodarczym Japonii - autor wskazywał na deflację jako główny powód stagnacji kraju ${ }^{6}$. W celu jej zwalczania amerykański ekonomista wytypował trzy główne obszary działania: reformy strukturalne, ekspansję fiskalną oraz niekonwencjonalna politykę monetarną ${ }^{7}$, które prawdopodobnie stały się inspiracją dla najważniejszych celów abenomiki - tzw. trzech strzał. Reflacjoniści postulowali politykę utrzymywania inflacji na średnim poziomie $2-3 \%$ rocznie i uważali między innymi, że kontrola banku centralnego nad podażą pieniądza może wyznaczyć poziom cen (ilościowa teoria pieniądza) ${ }^{8}$. W Japonii jednym z największych zwolenników takiej polityki był Koichi Hamada, profesor ekonomii na Uniwersytecie Yale i jeden z doradców Abego w okresie między jego pierwszą a drugą kadencją na stanowisku premiera (2007-2012). Hamada jest też uznawany za twórcę pojęcia „abenomika”. Prezentował on poglądy zbliżone do poglądów ekonomistów takich

3 S.P. Armstrong, The politics of Japan-China trade and the role of the world trade system, „World Economy" 2012, vol. 35, no. 9, s. 2.

4 J. Przystup, The Foreign Policy of Abe Shinzo: Strategic Vision and Policy Implementation, 5.02.2015, http://www.theasanforum.org/the-foreign-policy-of-abe-shinzo-strategic-vision-and-policy-implementation/ (dostęp: 21.03.2020).

5 Termin ten został po raz pierwszy użyty w Japonii i nie jest rozpowszechniony w literaturze; zob. też: I. Yeo, Debating Abenomics, „Seoul Journal of Japanese Studies” 2017, vol. 3, no. 1.

6 Ibidem, s. 62.

7 P. Krugman, Japan's Trap, maj 1998, https://web.mit.edu/krugman/www/japtrap.html (dostęp: 21.03.2020).

8 I. Yeo, Debating Abenomics..., s. 62-64.

9 S. Lechevalier, B. Monfort, Abenomics..., s. 6. 
jak Krugman i przedstawiał byłemu premierowi amerykański dyskurs na temat japońskiej polityki gospodarczej. W tym samym tonie Iwata Kukuo, były zastępca prezesa Banku Japonii, krytykował pasywną politykę luzowania ilościowego, czyli zwiększania przez bank podaży pieniądza w obiegu, co było realizowane od $2001 \mathrm{r}$. Optował za jednoczesnym wprowadzeniem konkretnego celu inflacyjnego (jak postulowali reflacjoniści) oraz nieograniczonym luzowaniem polityki pieniężnej, aby odwrócić procesy deflacyjne w Japonii. Zmierzał w ten sposób do wzmocnienia słabnącego jena i w efekcie do podniesienia cen. W tym kontekście Kukuo nie zgadzał się z opiniami głoszącymi, że źródłem problemów gospodarczych kraju było przede wszystkim szybko starzejące się społeczeństwo ${ }^{10}$.

Zwolennicy abenomiki wskazywali także historyczne dowody na skuteczność takich zabiegów. Przykładem była polityka japońskiego ministra finansów Takahashiego Korekiya w okresie tzw. depresji Shōwa w latach 1930-1932. Kryzys ten został wywołany nie tylko krachem na Wall Street w październiku 1929 r. i postępująca za nim Wielką Depresją, lecz także aktywna polityką deflacyjną w kraju, która miała na celu przede wszystkim wyeliminowanie słabych banków i przedsiębiorstw, jak również przygotowanie się na powrót do przedwojennego parytetu złota (z ustalonym kursem wymiany ${ }^{11}$. W ramach reform kolejny rząd zaczął prowadzić politykę luzowania ilościowego na znacznie większą skalę niż w poprzednich okresach, a także zwiększał wydatki fiskalne poprzez emisję obligacji rządowych, które następnie były wykupywane przez japońskie banki. Dzięki temu wyprowadzono gospodarkę z recesji o wiele szybciej niż miało to miejsce w Stanach Zjednoczonych i Europie. Krytycy wskazywali jednak negatywne efekty tej polityki: mniejszą dyscyplinę finansowa, większą kontrolę państwa i silniejszy wpływ armii, co ostatecznie ułatwiało prowadzenie imperialnej polityki w regionie $^{12}$. Po zabójstwie Korekiyo w roku 1936 w Japonii inflacja zaczęła wyraźnie wzrastać, jako że następcy ministra byli niechętni obcinaniu wprowadzonych za kadencji swoich poprzedników dodatkowych źródeł dochodu dla rządu ${ }^{13}$.

W opisanych wyżej warunkach Shinzo Abe przedstawił w roku 2012 kompleksowy plan ożywienia japońskiej gospodarki, który miał składać się z trzech „strzał”: agresywnego luzowania ilościowego (które miało powstrzymać deflację), elastycznej polityki fiskalnej (potrzebnej do ożywienia popytu) oraz reform strukturalnych (stymulujących wzrost poprzez inwestycje prywatne) ${ }^{14}$. Te trzy cele miały być ze

\footnotetext{
10 I. Yeo, Debating Abenomics..., s. 62.

11 The 1930s and War Economy, https://www.grips.ac.jp/teacher/oono/hp/lecture_J/lec09.htm (dostęp: 22.03.2020).

12 I. Yeo, Debating Abenomics..., s. 62.

13 J.M. Schlesinger, T. Nakamichi, As Japan Battles Deflation, a Bitter Legacy Looms, „The Wall Street Journal", 11.06.2015, https://www.wsj.com/articles/as-japan-battles-deflation-a-bitter-legacy-looms-1434011826?tesla=y (dostęp: 22.03.2020).

14 K. Aramaki, Japan's Long Stagnation, Deflation, and Abenomics: Mechanisms and Lessons, Singapore 2018, s. 286.
} 
sobą skoordynowane, co stanowiło istotną zmianę w porównaniu do działań poprzedników Abego - w przeszłości rozwiązania takie stosowano wybiórczo lub w zupełnie odwrotny sposób. Przykładem mogła być polityka Banku Japonii w latach 2008-2013, który bronił tezy, że polityka monetarna nie jest w stanie wpłynąć na główne przyczyny deflacji. Warunkiem aktywniejszych działań w sferze monetarnej, jak przekonywał Bank, mogły być tylko reformy strukturalne oraz konsolidacja długu publicznego ${ }^{15}$. Program abenomiki w zamierzeniu miał skupiać się na różnych aspektach polityki ekonomicznej, by w sposób gruntowny i długotrwały pobudzić gospodarkę. Krytycy uważali jednak, że abenomika, bazując na teoriach reflacjonistów, w gruncie rzeczy ogniskuje się tylko wokół pierwszej „strzały”, reszta natomiast była narzędziem do osiagania celów politycznych premiera. Ocenia się, że sam pomysł oparcia programu na tych trzech celach jest wynikiem kompromisu zawartego między najważniejszymi decydentami Partii Liberalno-Demokratycznej, a jedynie pierwszy punkt miał być idea Abego ${ }^{16}$. Sam polityk dla uzasadnienia swoich trzech „strzał” przywoływał przypowieść z końca epoki Edo, z której płyną morał, że jedna strzała może być z łatwościa przełamana, natomiast wystrzelenie pęku trzech gwarantuje sukces ${ }^{17}$. Mimo to koordynacja między tak odmiennymi ideologicznie planami w gruncie rzeczy musiała być ograniczona, co nie znaczyło, że niemożliwa.

Główne założenie planu, a więc powstrzymanie deflacji, miało zostać osiagnięte poprzez luzowanie ilościowe (we współpracy z bankiem centralnym) oraz bodźce fiskalne. W ten sposób zamierzano doprowadzić do zmniejszenia realnych stóp procentowych oraz pobudzenia konsumpcji i inwestycji. W przypadku osłabienia jena również japońscy producenci mogliby sprzedawać więcej produktów za granicę, zwiększając przez to eksport. Przeprowadzenie reform strukturalnych zwiększyłoby w krótkiej perspektywie zaufanie, a w dłuższej - zapewniłoby wzrost gospodarczy. To z kolei pozwoliłoby zmniejszyć dług publiczny. Zarazem jednak Abe zdawał sobie sprawę, że nie można w nieskończoność stymulować popytu środkami publicznymi, ale trzeba opracować strategię, w ramach której to aktywność przedsiębiorstw umożliwiłaby tworzenie nowych miejsc pracy i podnoszenie wysokości wynagrodzeń ${ }^{18}$. Sukces tego planu oznaczałby wyrwanie trzeciej pod względem wielkości gospodarki na świecie z długotrwałego okresu marazmu. Niewattpliwie miałoby to wpływ nie tylko na ten duży rynek krajowy, lecz także na gospodarkę regionalną i światową, której Japonia jest ważną częścią.

\footnotetext{
15 S. Lechevalier, B. Monfort, Abenomics..., s. 7.

16 I. Yeo, Debating Abenomics..., s. 66.

17 J. Grabowiecki, M. Dabrowski, Abenomics and its impact on the economy of Japan, „Optimum. Studia Ekonomiczne" 2017, nr 5(89), s. 25.

18 D. Botman, S. Danninger, J. Schiff, Can Abenomics Succeed? Overcoming the Legacy of Japan's Lost Decades, Washington 2015, s. 3.
} 


\section{Wprowadzenie planu w życie}

Krótko po nominacji nowego prezesa Banku Japonii, Haruhiko Kurody, 4 kwietnia 2013 r. instytucja ta ogłosiła nową politykę, nazywaną QQE (ang. quantitative and qualitative monetary easing - luzowanie ilościowe i jakościowe). Była to pierwsza „strzała" abenomiki, w ramach której Bank Japonii miał rozpocząć skupowanie w dużych ilościach rządowych obligacji od instytucji finansowych oraz inwestowanie w ryzykowne papiery wartościowe (funduszy indeksowych bądź funduszy na rynku nieruchomości). Program QQE zmierzał również do obniżenia długoterminowych stóp procentowych, co zwiększyłoby popyt krajowy i zmniejszyłoby lukę PKB (różnicę między wielkościa produkcji przy pełnym zatrudnieniu a PKB realnym). Ponadto ustalono osiagnięcie celu inflacyjnego na poziomie $2 \% \mathrm{w}$ ciagu 2 lat $^{19}$. Pomóc w tym miała także deprecjacja jena, do czego przyczyniło się zmniejszenie obaw co do wybuchu kolejnego kryzysu w Europie na przełomie 2012 i 2013 r. oraz polepszające się perspektywy dla gospodarki światowej w tamtym okresie.

Ważną kwestią dla rządu było unormowanie trudnej sytuacji fiskalnej państwa bez zbytniego hamowania i tak słabego już wzrostu gospodarczego. Relacja długu publicznego Japonii w stosunku do PKB wzrosła z 67\% w roku 1990 do 232\% w roku $2013^{20}$. Powiększająca się różnica między przychodami a wydatkami była finansowana głównie poprzez emisje obligacji skarbu państwa. Co ważne, 90\% długu znajdowało się w rękach japońskich, a popyt na te papiery był niezmiennie wysoki. Ograniczona liczba zagranicznych inwestorów zmniejszała ryzyko negatywnych konsekwencji ewentualnego ich wycofania w przypadku pogorszenia wiarygodności kraju, co wyraźnie odróżniało sytuacje japońską od innego wysoce zadłużonego kraju - Grecji ${ }^{21}$. Pomimo problemu kurczącej się populacji czy malejących oszczędności gospodarstw domowych przykład grecki pokazywał, że uregulowanie finansów bez wzrostu gospodarczego nie przynosi pożądanych skutków ${ }^{22}$. Dlatego też druga „strzała” planu miała polegać przede wszystkim na krótkookresowym stymulowaniu gospodarki, by następnie możliwe było rozpoczęcie konsolidacji fiskalnej.

W lutym 2013 r. przyjęto Ratunkowy Plan Ekonomiczny dla Odrodzenia Japońskiej Gospodarki (ang. Emergency Economic Policy for the Revival of the Japanese Economy). Składał się na niego krótkoterminowy pakiet stymulujący, opiewający na kwotę 210 mld USD (kwota najwyższa w historii, nie licząc kroków podjętych

19 Warto zauważyć, że poprzednie kierownictwo Banku Japonii również ustaliło taki cel, jednak bez podania limitu czasowego; zob. K. Aramaki, Japan's Long Stagnation..., s. 297.

20 MFW, General government gross debt, https://www.imf.org/external/datamapper/GGXWDG_ NGDP@WEO/OEMDC/ADVEC/WEOWORLD/JPN (dostęp: 29.03.2020).

21 J. Grabowiecki, M. Dąbrowski, Abenomics..., s. 27.

22 D. Botman, S. Danninger, J. Schiff, Can Abenomics Succeed?..., s. 4. 
po upadku amerykańskiego banku Lehman Brothers w roku 200823). Duża część tej kwoty (116 mld USD) miała być przeznaczona na inwestycje infrastrukturalne (przede wszystkim odbudowę mostów, tuneli i dróg uszkodzonych w wyniku trzęsienia ziemi i tsunami w 2011 r.). Rząd przeznaczył także ok. 30 mld USD na wsparcie programu emerytur pracowniczych ${ }^{24}$. Równocześnie planowano jednak również zacieśnienie finansów kraju, głównie poprzez stopniowa podwyżkę stawki podatku konsumpcyjnego. Działanie to zostało przełożone w czasie z powodu znaczacego spadku konsumpcji ${ }^{25}$ oraz wynikającego z tego słabszego, niż się spodziewano, wzrostu PKB. Sygnalizowało to toczący się spór między zwolennikami większej dyscypliny finansowej a doradcami premiera, którzy zalecali skupienie się w pierwszej kolejności na wzroście gospodarczym ${ }^{26}$. Można więc zauważyć, że stopniowo rząd Abego konsolidował finanse, podkreślając przy tym wagę inwestycji oraz konsumpcji w napędzaniu gospodarki.

Aby zniwelować wpływ pogarszającej się sytuacji demograficznej i przeprowadzanych reform fiskalnych, konieczne okazało się podniesienie potencjalnej stopy wzrostu gospodarczego, co można było osiagnąć przede wszystkim poprzez reformy strukturalne. Planowano, że efektem tych działań będzie stworzenie samonapędzającego się cyklu pożyczania oraz aktywnego inwestowania środków pieniężnych przez przedsiębiorstwa, co miało wpłynąc pozytywnie na liczbę miejsc pracy i wynagrodzenia pracownicze ${ }^{27}$. Strategie wzrostu wprowadzały także poprzednie rządy, jednak brakowało wyraźnych efektów takich programów, ponieważ omijały one najbardziej palące i najtrudniejsze politycznie do przeprowadzenia reformy ${ }^{28}$. Mając bezpieczną większość parlamentarną oraz uwzględniając oczekiwania zarówno społeczeństwa, jak i ekspertów, Abe mógł czuć przyzwolenie na to, by przeprowadzić śmielsze reformy aniżeli jego poprzednicy. W tym celu przyjęto w 2013 r. Strategię Rewitalizacji Japonii (ang. Japan Revitalization Strategy, zrewidowana w czerwcu 2014 r.). W planach tych skupiano się przede wszystkim na podniesieniu udziału kobiet oraz osób starszych na rynku pracy, a także liberalizacji i zwiększeniu produktywności sektora rolniczego ${ }^{29}$. Dualizm japońskiego rynku pracy (silnie chronieni pracownicy pełnoetatowi oraz rosnąca liczba atypowych umów o pracę³), przyczyniający się do nierówności pod względem pracy i płacy, utrudniał w szczególności

\footnotetext{
23 M. Yamanaka, List od Ambasadora Japonii w Polsce, 22.01.2013, https://jaap.pja.edu.pl/list-od-ambasadora-japonii-w-polsce/ (dostęp: 30.03.2020).

24 J. Grabowiecki, M. Dąbrowski, Abenomics..., s. 26.

25 Japan consumer spending, https://tradingeconomics.com/japan/consumer-spending (dostęp: 15.05.2020).

26 S. Lechevalier, B. Monfort, Abenomics..., s. 10.

27 M. Yamanaka, List od Ambasadora...

28 D. Botman, S. Danninger, J. Schiff, Can Abenomics Succeed?..., s. 5.

29 I. Yeo, Debating Abenomics..., s. 66.

30 Potocznie nazywanych ,umowami śmieciowymi”.
} 
sytuację kobiet po urodzeniu dziecka ${ }^{31}$. Ponadto trzecia „strzała” miała obejmować deregulację i obniżenie podatków dla przedsiębiorstw, automatyzację produkcji i usług oraz powstanie specjalnych stref ekonomicznych. Planowano wsparcie innowacji, utworzenie nowych rynków, np. usług medycznych czy energii, i rozwój relacji gospodarczych z innymi krajami ${ }^{32}$. Wszystkie te reformy miały spowodować efekt domina, rewitalizujący gospodarki lokalne i zachęcający do innowacji w małych i średnich przedsiębiorstwach ${ }^{33}$.

Zaangażowanie premiera w sprawy zagraniczne skutkowało decyzją o zwiększeniu poziomu umiędzynarodowienia kraju, zwłaszcza w odniesieniu do zawierania nowych umów handlowych, co stało się wręcz filarem reform strukturalnych abenomiki. Pomimo że Japonia była jednym z największych eksporterów oraz importerów na świecie, udział wymiany handlowej w gospodarce kraju pozostawał niższy (natomiast nadal ważny) niż w krajach Unii Europejskiej, a nawet na rozwijających się rynkach azjatyckich. Wpływ na ten stan rzeczy mógł mieć niższy stopień umiędzynarodowienia grup spółek keiretsü ${ }^{34}$. Najważniejszą decyzją podjętą w celu głębszego zintegrowania Japonii z rynkami światowymi było przystapienie do Partnerstwa Transpacyficznego (ang. Trans-Pacific Partnership, TPP), zrzeszającego 12 krajów po obu stronach Pacyfiku, w tym m.in. Stany Zjednoczone, Kanadę, Australię i Meksyk. Brakowało w nim jednak zarówno Chin, jak i Korei Południowej, mimo że ta podpisała na początku drugiej dekady XXI w. wiele umów handlowych z USA i Unia Europejską. Fakt ten skłonił rząd japoński, wbrew opozycji ze strony lobby rolniczego oraz większości partii rządzącej, do ogłoszenia na początku 2013 r. decyzji o dołączeniu do porozumienia ${ }^{35}$. Ponadto w 2019 r. podpisano umowę o partnerstwie gospodarczym między Japonią a Unią Europejską, obejmującą wspólnie obszar o wartości ok. 30\% światowego $\mathrm{PKB}^{36}$. Większa integracja Japonii z rynkiem światowym pozwoliłaby przede wszystkim na deregulację $\mathrm{w}$ tak chronionych do tej pory sektorach jak rolnictwo czy usługi, ale też na zabezpieczenie rynków eksportowych oraz ustanowienie międzynarodowych zasad dotyczących przepływu kapitału, co pozytywnie wpłynęłoby na wzrost gospodarczy w coraz bardziej protekcjonistycznym otoczeniu.

31 OECD, Employment. Improving the labour market outcomes of women, Japan Policy Brief, April 2017, s. 2, https://www/oecd.org/japan/japan-improving-the-labour-market-outcomes-of-women.pdf (dostęp: 31.03.2020).

32 J. Grabowiecki, M. Dąbrowski, Abenomics..., s. 28.

33 S. Shibata, Re-packaging old policies? 'Abenomics' and the lack of an alternative growth model for Japan's political economy, „Japan Forum” 2017, vol. 29, no. 3, s. 408.

34 J. Grabowiecki, M. Dąbrowski, Abenomics..., s. 28.

35 S. Lechevalier, B. Monfort, Abenomics..., s. 11.

36 J. Grabowiecki, M. Dąbrowski, Abenomics..., s. 28. 
Po wygraniu przedterminowych wyborów w 2014 r. premier Abe postanowił zaprezentować kolejną odsłonę swojego sztandarowego programu, zawierającego „trzy nowe strzały". Z pewnościa miało to na celu ukazanie nowego otwarcia w polityce rządu w świetle niesatysfakcjonujących efektów abenomiki. Choć krajowi udało się wyjść z deflacji, to do 2015 r. nie osiagnięto ustalonego na 2\% celu inflacyjnego, a wzrost gospodarczy pozostawał na niskim poziomie. $\mathrm{Na}$ horyzoncie widniała również kolejna podwyżka podatku konsumpcyjnego (z 8\% do 10\%), która została pierwotnie przełożona z powodu większego niż się spodziewano negatywnego wpływu pierwszej podwyżki na wzrost gospodarczy i konsumpcję. Niektórzy postulowali kolejne odłożenie wprowadzenia tego podatku (planowanego teraz na kwiecień 2017 r.), jednak premier w tamtym okresie odrzucał takie głosy, twierdząc, że do tego czasu „,kluczowe jest wprowadzenie japońskiej gospodarki na trend rosnący”, czemu przysłużyć się mają właśnie owe „nowe trzy strzały”37.

Nowy plan miał skupić się na szerszych problemach nękających Japonię, takich jak starzejące się społeczeństwo, zmniejszający się zasób siły roboczej i w efekcie mniejsze zachęty do inwestowania w kurczący się rynek. Abenomika 2.0 wydawała się więc naturalnym przedłużeniem trzeciej strzały oryginalnego planu, a więc reform strukturalnych. Plan Abego składał się z następujących elementów: 1) silna ekonomia, 2) wsparcie dla rodzin z dziećmi i 3) bezpieczeństwo socjalne. Dla każdego z nich wyznaczono również oczekiwane rezultaty: PKB na poziomie 5 bln USD do roku 2020, zwiększenie współczynnika dzietności do poziomu 1,8 oraz osiagnięcie do połowy lat 20. stanu, w którym nikt nie będzie musiał rezygnować z pracy, by opiekować się osobami starszymi ${ }^{38}$. W celu odwrócenia negatywnego trendu spadającej liczby urodzeń i starzenia się społeczeństwa ważne było, według premiera, utrzymanie przez kolejnych 50 lat populacji na poziomie $100 \mathrm{mln}$ (przy obecnej liczbie ok. $127 \mathrm{mln})^{39}$.

Chociaż nowy plan premiera Abego skupial się na kwestiach strukturalnych o charakterze kluczowym dla przyszłości kraju, wielu ekspertów go krytykowało, a przynajmniej dziwiła ich taka zmiana paradygmatów rządu. Po pierwsze, podstawowe założenie pierwotnego planu, a więc osiagnięcie i utrzymanie celu inflacyjnego na poziomie 2\%, nie zostało osiagnięte do 2015 r., nie mówiąc już o silniejszym wzroście gospodarczym. Ponadto upłynęło za mało czasu, by móc dokładnie

37 Debate Surrounding the „New Three Arrows” of Abenomics, Foreign Press Center Japan, 12.08.2015, https://fpcj.jp/en/j_views-en/magazine_articles-en/p=38092/ (dostęp: 8.04.2020).

38 H. Hayakawa, Reading Between the Lines of Abenomics 2.0, Nippon.com, 16.12.2015, https:// www.nippon.com/en/currents/d00207/reading-between-the-lines-of-abenomics-2-0.html (dostęp: 8.04.2020).

39 Debate... 
odpowiedzieć na pytanie o skuteczność abenomiki. Dotychczasowe efekty, pomimo zachęcających sygnałów, nie sprostały ani założeniom rządu, ani oczekiwaniom rynków. Jedynie pierwsza „strzała”, a więc polityka monetarna, była kontynuowana, natomiast stymulowanie fiskalne zostało zatrzymane przez podwyżkę podatku w 2014 r. (skądinąd również potrzebnego gospodarce). Reformy strukturalne nie dotknęły natomiast najważniejszych sfer gospodarki i stanęły w miejscu. Co więcej, nowy plan został zaprezentowany na podstawie stwierdzeń, że problem deflacji został w większej części rozwiązany, te jednak wydawały się przedwczesne. Po drugie, problematyczny był fakt, że nie opisano ścieżki dochodzenia do tych trzech nowych celów, co odróżniało je od oryginalnej abenomiki, której założenia miały być realizowane według konkretnych rozwiązań. Były one również luźniej ze sobą związane niż trzy pierwsze „strzały”, dlatego krytycy określali całokształt planu jako chaotyczny ${ }^{40}$.

Bez konkretnego planu realizacji abenomika 2.0 wydawała się również myśleniem życzeniowym. Postulat osiagnnięcia PKB na poziomie 5 bln USD do roku 2020 wiązał się z wymogiem osiagnięcia rocznego wzrostu nominalnego na poziomie 3\%, podczas gdy sam rząd prognozował ten wskaźnik tylko na poziomie $0,5 \%{ }^{41}$. Tym bardziej dane te skłaniały do stawiania pytań o sposób osiagnięcia zamierzonych celów. Ponadto wzrost współczynnika dzietności z poziomu wynoszącego niewiele ponad 1,4 w roku $2015^{42}$ do poziomu 1,8 w ciagu mniej niż dekady już wtedy wydawał się mało prawdopodobny bez znacznego podniesienia wydatków na zasiłki rodzinne czy budowę żłobków. Również kwestie kulturowe utrudniały podniesienie liczby urodzeń, gdyż coraz więcej Japonek odkładało w czasie decyzję o urodzeniu dziecka. Przyczyną tego zjawiska były rosnące możliwości na rynku pracy i zwiększająca się liczba młodych osób, które w ogóle nie decydowały się na życie w związku. Trzecia „nowa strzała”, a więc zmniejszenie obciążenia opieką nad starszymi, była problematyczna z powodu statystycznego wchodzenia osób z powojennego wyżu demograficznego w wiek $75+$ z początkiem roku 2020 , co oznaczało znaczny wzrost kosztów za ich opiekę ${ }^{43}$. W tym kontekście jedyne obietnice, które zostały przedstawione w ramach drugiej odsłony abenomiki, to ułatwienie dostępu do żłobków i bezpłatne przedszkola ${ }^{44}$, także wymagające poniesienia kosztów. Nietrudno więc oprzeć się wrażeniu, że abenomika 2.0 została wprowadzona bez należytego opracowania jej założeń i analizy funkcjonowania pierwotnego planu.

\footnotetext{
${ }^{40}$ H. Hayakawa, Reading Between the Lines...

41 Ibidem.

42 Fertility rate, total (births per woman) - Japan, The World Bank, https://data.worldbank.org/ indicator/SP.DYN.TFRT.IN?locations=JP (dostęp: 9.04.2020).

43 H. Hayakawa, Reading Between the Lines...

44 Looming election returns Abe's focus to economy, Nikkei Asia, 25.09.2015, https://asia.nikkei.com/
} Politics-Economy/Policy-Politics/Looming-election-returns-Abe-s-focus-to-economy (dostęp: 11.04.2020). 
Jak wspomniano, pierwsza podwyżka podatku konsumpcyjnego w 2014 r. wywarła większy, niż się spodziewano, negatywny wpływ na wzrost gospodarczy w kraju oraz znacząco ograniczyła konsumpcję. Jednocześnie fakt ten spowodował ogólne podwyżki w cenach, co skłoniło rząd do ogłoszenia końca deflacji w Japonii. Dodatkowymi okolicznościami, świadczącymi o odbiciu gospodarczym kraju, był spadek cen ropy i nominalny wzrost wynagrodzeń dla pracowników. Również zyski japońskich spółek, a więc podstawowy warunek inwestowania, zwiększyły się o 30\% między 2012 i 2014 r., co z kolei poprawiło nastroje na rynku oraz doprowadziło do osiagnięcia najniższej liczby bankructw w ciagu ostatnich 25 lat. Świadczyło to o znaczącej poprawie kondycji firm, co było istotnym sukcesem, zwłaszcza po kryzysach w 2008 i 2011 r. Fakt ten wpływał również na sytuację pracowników, o czym świadczył wzrost zatrudnienia o 1,1 mln w okresie od czwartego kwartału 2014 r. do października 2015 r. i spadająca stopa bezrobocia (3,1\% w 2016 r.). Rząd pominął przy tym wzrost cen akcji i deprecjację jena, które, według krytyków, były głównymi przyczynami rosnących zysków firm i słabo odczuwalnego wpływu lepszych wyników gospodarczych na poziom konsumpcji prywatnej. Poprawa wyników ekonomicznych japońskich przedsiębiorstw nie spowodowała także, jak się spodziewano, większej liczby inwestycji. Przyczyną tego procesu był bowiem głównie słabnący jen. Wynikający z poprawy konkurencyjności cenowej wzrost wolumenu eksportu okazał się niezbyt wysoki. Słabnący jen i wzrost cen importu powodowały realny spadek wynagrodzeń ${ }^{45}$. Zatem mimo poprawy stanu gospodarki Japonii nadal nie osiagnięto wzrostu gospodarczego na poziomie sprzed $1990 \mathrm{r}$., a nawet $2007 \mathrm{r}$.

$\mathrm{Z}$ tego powodu rząd postanowił mocniej skupić się na reformach, czy to w ramach abenomiki 2.0, czy też tzw. Strategii Rewitalizacji Japonii, zaprezentowanej w 2015 r. Ta ostatnia zakładała stopniowe zmniejszanie luki deflacyjnej, a więc nadwyżki podaży nad popytem, poprzez poprawę wydajności firm, a co za tym idzie - zwiększenie stopy zatrudnienia. Było to ważne tym bardziej, że również podaż mogła w bliskiej przyszłości napotykać na ograniczenia wynikające ze spadającej liczby ludności oraz liczby osób w wieku produkcyjnym. Poprawa produkcyjności wydawała się więc w tym względzie kluczowa dla wzrostu gospodarczego Japonii, w czym miały pomóc inwestycje rządowe i tzw. lokalne abenomiki, służące, tak jak oryginalna trzecia „strzała”, reformom gospodarek lokalnych, a w szczególności sektorom usług, rolnictwa i turystyki. Rząd zobowiązał się ponadto nadal rozwijać perspektywiczne sektory, takie jak usługi medyczne, energię odnawialną, sport i renowację budynków.

W odniesieniu do polityki monetarnej, z powodu postępujących problemów $z$ osiagnięciem celu inflacyjnego na poziomie $2 \%$ i pomimo polityki luzowania ilościowego na ogromną skalę, Bank Japonii w styczniu 2016 r. ogłosił kontynuację

45 I. Yeo, Debating Abenomics..., s. 72. 
tego programu, tym razem jednak towarzyszył mu dodatkowy element w postaci negatywnych stóp procentowych na poziomie $-0,1 \%$ na rachunkach bieżących. Ruch tej instytucji został przyjęty nieprzychylnie na rynkach oraz był postrzegany jako niespodziewany, a także niespójny z wcześniejszą polityką skupowania obligacji. Choć miał na celu jak najszybsze dojście do inflacji na poziomie $2 \%$, to w krótkim czasie doprowadził do wzrostu wartości jena oraz ponownej deflacji w kraju. Mimo to Bank Japonii w kolejnych komunikatach zobowiązał się do kontynuowania polityki luzowania ilościowego z jednoczesną kontrolą krzywej dochodowości (pokazującej oprocentowanie obligacji w różnych terminach zapadalności). Wprowadzenie polityki negatywnej stopy procentowej spowodowało spłaszczenie tej stopy (a więc obligacje długoterminowe stawały się mniej rentowne, odzwierciedlając tym samym negatywne reakcje rynku $)^{46}$.

\section{Ocena dotychczasowych efektów abenomiki}

Pomimo agresywnej polityki luzowania ilościowego, wprowadzonej w 2013 r. przez Bank Japonii wraz z jej rewizjami w późniejszych latach, nadal nie udało się zrealizować założonego celu inflacyjnego na poziomie $2 \%$ (rys. 1). Choć kraj zdołał wyjść ze stanu panującej długo deflacji, to osiagane wyniki nie przekraczały poziomu nawet $1 \%$. Wskaźnik cen towarów i usług konsumpcyjnych spadł do poziomu poniżej $0 \mathrm{w} 2016$ r., co po raz ostatni miało miejsce przed wprowadzeniem całego planu abenomiki. W związku z tymi pesymistycznymi danymi ponownie przełożono w 2017 r. podwyżkę podatku konsumpcyjnego z 8\% do 10\%. Ostatecznie został on wprowadzony w październiku 2019 r., co, zważywszy na efekt pierwszej podwyżki w 2014 r., może znowu negatywnie wpłynać na wzrost gospodarczy i konsumpcję - może o tym świadczyć spadająca inflacja. Niemniej jednak zarówno bank centralny, jak i rząd zapewniają o kontynuacji wdrażania dotychczasowych strategii ${ }^{47}$, które wydaja się być popierane przez obywateli w kolejnych wygranych przez Partię Liberalno-Demokratyczną wyborach w 2017 i 2019 r. Te drugie wybory nie zapewniły jednak partii rządzącej większości konstytucyjnej potrzebnej do zmiany ustawy zasadniczej, co przez długi okres było zasadniczym celem premiera ${ }^{48}$.

46 S. Shirai, Overview of Japan's Unconventional Monetary Policy, October 2016, https://www.nbp.pl/ badania/konferencje/2016/6th-Annual-NBP/pdf/Sayuri_Shirai.pdf (dostęp: 16.04.2020).

47 I. Yeo, Debating Abenomics..., s. 76.

48 Y. Wakatsuki, Sbin₹o Abe declares victory in Japan election but fails to win super majority, CNN, 22.07.2019, https://edition.cnn.com/2019/07/22/asia/japan-election-result-intl-hnk/index.html (dostęp: 17.04.2020). 


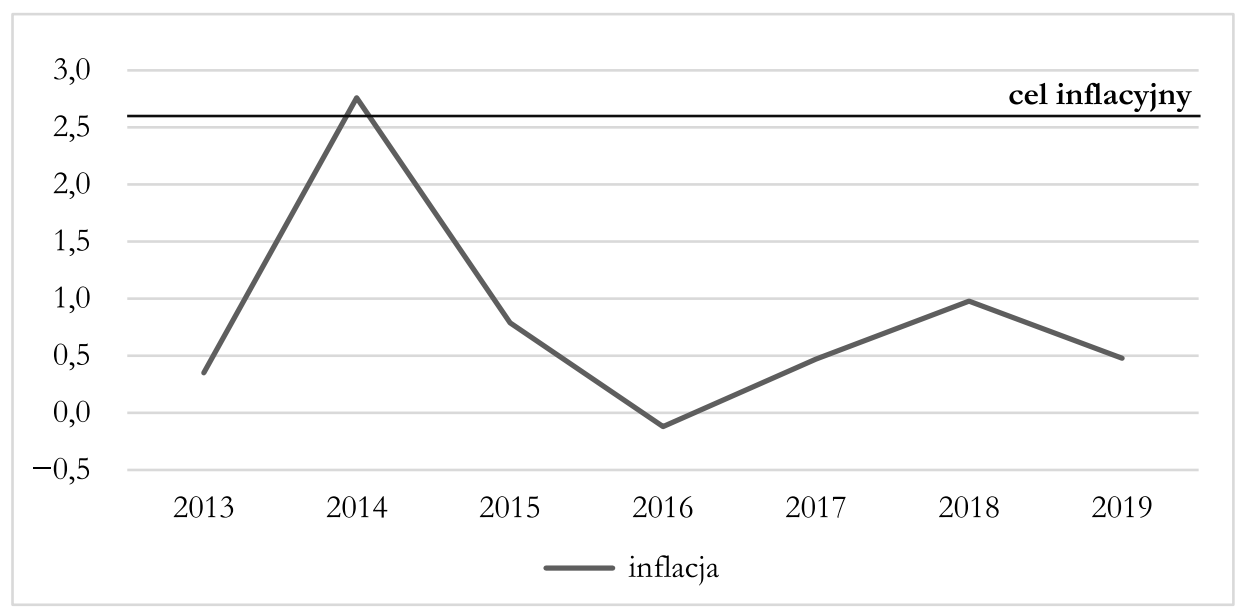

Rys. 1. Inflacja CPI w Japonii od czasu wprowadzenia planu abenomiki (\%)

Źródło: Opracowanie własne na podstawie: OECD, Inflation (CPI) (indicator), 2019, doi: 10.1787/ eee82e6e-en (dostęp: 17.04.2020).

Drugi kluczowy wskaźnik, a więc wzrost gospodarczy, również nie podnosił się w takim tempie jak oczekiwali tego decydenci, zwłaszcza w porównaniu do 17 państw strefy euro bądź wszystkich krajów Organizacji Współpracy Gospodarczej i Rozwoju (OECD) (rys. 2). Począwszy od 2013 r., jedynie w 2017 r. realny wzrost PKB wyniósł więcej niż 1,5\%, co nadal było wynikiem przeciętnym i odbiegającym od wyników innych wiodących gospodarek na świecie. Po części gorsze wyniki tłumaczy się spowolnieniem na rynkach wschodzących oraz na rynku największego partnera handlowego Japonii, czyli Chin. Kluczowa była tutaj jednak polityka wewnętrzna. Sprzeczność między drugą „strzałą” abenomiki, a więc stymulowaniem fiskalnym (co na samym początku rzeczywiście pobudziło wzrost), a potrzebą równoważenia rekordowo wysokiego długu publicznego (głównie poprzez podnoszenie podatków) zaburzała konsumpcję, powodowała stagnację, a w niektórych kwartałach nawet recesję. Drugim często wskazywanym powodem były niewystarczające reformy, zwłaszcza w sferze zgłaszanej przez przedsiębiorców deregulacji. Zatem mimo że przeprowadzono wiele reform strukturalnych w ramach trzeciej „strzały” i zapewniano o zaangażowaniu w dwie pozostałe, na razie nie widać efektów takiej polityki.

Abenomika podczas całego okresu jej realizacji wywarła bardzo mały wpływ na poprawę relacji długu publicznego do PKB. Skala pierwszego programu QQE wyraźnie zwiększyła tę relację do rekordowego poziomu ponad 238\% w $2014 \mathrm{r}$. Od tamtego czasu zaczęto obserwować niewielki spadek tego wskaźnika, przypuszczalnie dzięki wprowadzeniu pierwszej podwyżki podatku konsumpcyjnego w roku 2014. Choć przychody z podatków w kolejnych latach rosły, to jednocześnie w takim 


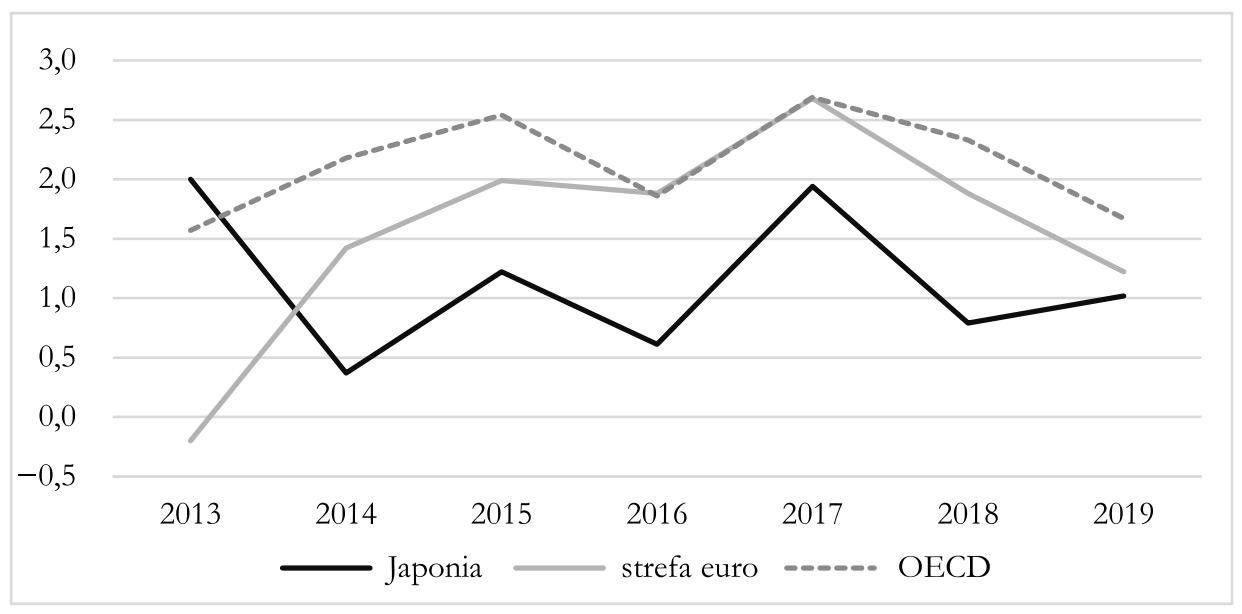

Rys. 2. Realny wzrost PKB w Japonii, strefie euro oraz krajach OECD w okresie 2013-2019 (\%) Źródło: Opracowanie własne na podstawie: OECD, Real GDP Forecast (indicator), 2020, doi: 10.1787/ b86d1fc8-en (dostęp: 17.04.2020).

samym tempie wzrastały wydatki na system ubezpieczeń społecznych, obronność i obsługę długu publicznego. Obiecywane w tym zakresie reformy są nadal w fazie planowania i nie wydaje się, by miały wejść w życie w najbliższej przyszłości. Tylko usprawnienia systemu podatkowego (m.in. zmiana sposobu naliczania podatku dochodowego czy stworzenie nowych warunków dla firm chcących otrzymać ulgi podatkowe w roku 2018) są konsekwentnie realizowane ${ }^{49}$.

Pomimo podwyżek podatków program luzowania ilościowego w ramach pierwszej „strzały”, a więc rokroczne skupywanie przez Bank Japonii obligacji rządowych, naturalnie powodował wzrost zadłużenia. Głównym powodem takiego stanu rzeczy były słabe wyniki w poprzednio rozpatrywanych sferach, a więc we wzroście inflacji oraz PKB. Zakładany przez rząd efekt domina zatem nie nastąił, gdyż, pomimo deprecjacji jena i zwiększonego stymulowania fiskalnego, popyt i konsumpcja nie wzrosły, a wynagrodzenia poprawiły się minimalnie. Osobną kwestią są wydatki przeznaczone na tzw. kiełbasę wyborcza, służące zdobyciu dodatkowego poparcia tuż przed zaplanowanymi wyborami, co jest stała praktyką partii rządzącej, odzwierciedlającą się np. w udzielaniu wsparcia dla rolników ${ }^{50}$. W tej dziedzinie jedynym sukcesem jest stopniowe zmniejszanie deficytu budżetowego (z poziomu 7,8\% w relacji do PKB w 2013 r. do 4,5\% w 2017 r. ${ }^{51}$ ), aczkolwiek plany jego całkowitego

49 Ministerstwo Finansów Japonii, Tax Reform (Main Points), FY2018, Tokyo 2017, s. 1-4, https://www.mof.go.jp/english/tax_policy/tax_reform/fy2018/tax2018a.pdf (dostęp: 18.04.2020). 50 M. Craig, The Abe Restoration: Contemporary Japanese Politics and Reformation, Lanham 2016, s. 137.

51 Ministerstwo Finansów Japonii, Japanese Public Finance Fact Sheet, Tokyo 2017, s. 11, https:// www.mof.go.jp/english/budget/budget/fy2017/04.pdf (dostęp: 19.04.2020). 
zniwelowania do roku 2020 wydają się niemożliwe do zrealizowania. Pomimo że do tej pory wysoki stosunek długu publicznego do PKB nie spowodował kryzysu państwa, to przedłużona stagnacja gospodarcza oraz deprecjacja jena moga w przyszłości stanowić zagrożenie dla stanu finansów publicznych Japonii.

Ostatnim aspektem, nad którym warto się pochylić w celu oceny skutków polityki premiera Abego, jest sytuacja na rynku pracy. Z jednej strony stopa bezrobocia systematycznie spadała, na co mogą mieć wpływ przede wszystkim wyższe zyski przedsiębiorstw oraz reformy przeprowadzone przez rząd po 2013 r. Ponadto stopa zatrudnienia stale wzrasta (z poziomu 71,8\% ludności w wieku produkcyjnym w 2013 r. do 77,7\% w 2019 r. ${ }^{52}$ ). Problemem jest jednak nadal wysoki odsetek osób pracujących w ramach atypowych umów o pracę (niezmiennie od $2014 \mathrm{r}$. ok. 37-38\% wszystkich pracowników). Wiąże się to przede wszystkim ze spadkiem liczby osób samozatrudnionych (głównie rolników pracujących dorywczo oraz właścicieli tradycyjnych sklepów detalicznych, których pracownicy zatrudniają się na część etatu w supermarketach). Jednocześnie obserwuje się zwiększony stosunek pracowników zatrudnionych na czas nieokreślony do wszystkich osób zatrudnionych (z 56,6\% w pierwszym kwartale 2014 r. do 59,1\% w drugim kwartale 2019 r. $)^{53}$. Dodatkowo wzrasta zakładane przez rząd zatrudnienie osób w wieku powyżej 65 lat (o 2,1 mln więcej między 2014 i 2019 r.). Są to osoby, które ukończyły edukację w tzw. epoce lodowcowej zatrudnienia z przełomu XX i XXI w. Nie miały one wtedy możliwości podejmowania pracy w formie innej niż na podstawie atypowych umów o pracę, a obecnie także zdobycie regularnego zatrudnienia stanowi dla nich problem.

Pomimo jednak polepszającego się klimatu na rynku pracy średnie wynagrodzenie w okresie 2013-2018 rosło w znacząco wolniejszym tempie w porównaniu do innych wiodących gospodarek światowych oraz średniej dla OECD (rys. 3), nawet w sytuacji powiększających się niedoborów siły roboczej. Duży wpływ na ten stan ma opisywana już wysoka różnica w zarobkach między regularnymi pracownikami a osobami zatrudnionymi na podstawie atypowych umów o pracę, z czym rząd Abego stara się walczyć. Dużym problemem jest również opór sektora prywatnego w odniesieniu do reform strukturalnych, co symbolicznie przejawia się w nadal powszechnie używanych w miejscach pracy faksach i hanko (oficjalnych pieczęciach) ${ }^{54}$. Japońskie przedsiębiorstwa pozostają mało wydajne i nie nadążaja za zmianami technologicznymi. W związku z tym w ciagu ostatnich 20 lat, niezależnie od

52 OECD, Unemployment rate (indicator), 2019, doi: 10.1787/997c8750-en (dostęp: 19.04.2020).

53 M. Takenaka, The ratio of regular workers is on the rise, "The Japan Times”, 28.11.2019, https:// www.japantimes.co.jp/opinion/2019/11/28/commentary/japan-commentary/ratio-regular-workers-rise/\#.Xpw4tZngrIU (dostęp: 19.04.2020).

54 M. Heazle, Abe's domestic failings may cost Japan and the region-dearly, The Strategist, https://www. aspistrategist.org.au/abes-domestic-failings-may-cost-japan-and-the-region-dearly/ (dostęp: 14.06.2020). 
spadającej okresowo stopy bezrobocia, pensje rosły bardzo wolno. Pomimo stale spadającego bezrobocia sytuacja na rynku pracy podczas rządów premiera Abego nie uległa znaczącej poprawie.

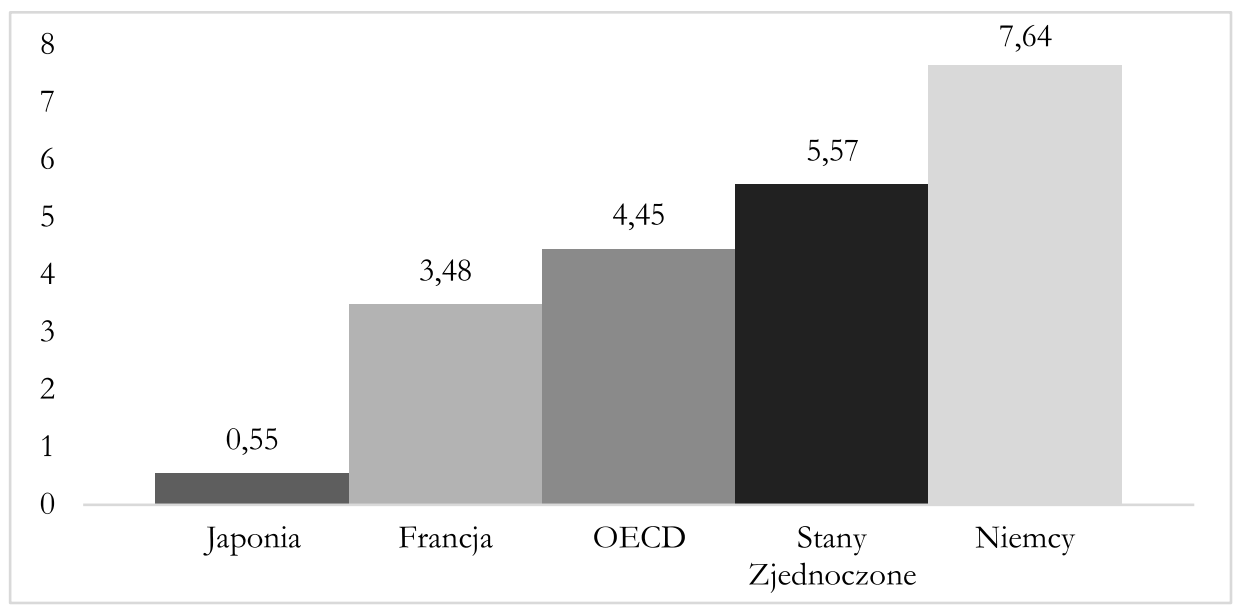

Rys. 3. Porównanie zmian średniego wynagrodzenia w dolarach u wybranych państw oraz OECD w okresie 2013-2018 (\%)

Źródło: Opracowanie własne na podstawie: OECD, Average wages (indicator), 2020, doi: 10.1787/cc3e1387-en (dostęp: 19.04.2020).

\section{Przyszłość abenomiki oraz Japonii w obliczu epidemii COVID-19}

Biorąc pod uwagę zarówno najnowsze dostępne dane, jak i całość funkcjonowania programu abenomiki, nie udało się osiagnąć zamierzonego celu inflacji na poziomie $2 \%$ ani wyraźnie wyższego wzrostu PKB. Nie należy przy tym całkowicie negować założeń tego planu, jednak ich realizacja okazała się niekompletna, zwłaszcza w sferze wewnętrznych reform strukturalnych. Z jednej strony gospodarka wyszła ze stanu chronicznej deflacji, trwającej ok. 20 lat, a realne PKB stale wzrastało. Ponadto stopa bezrobocia spadła poniżej poziomu $2,5 \%$, w czym udział miało większe zatrudnienie kobiet oraz osób w wieku powyżej 65 lat na rynku pracy. Zakrojony na szeroką skale program luzowania ilościowego, czyli główne narzędzie abenomiki, przyniósł tylko nieznaczna poprawę w odniesieniu do inflacji, której wzrost zakończył się z chwila podniesienia stawki podatku konsumpcyjnego w roku 2014. Ten sam ruch uderzył również w konsumpcję, spowalniając dopiero co przyspieszający po słabym okresie wzrost gospodarczy, a w następnych latach nadal rósł on w wolnym tempie. Dodanie kolejnych celów do programu w ramach tzw. nowych trzech strzał można postrzegać bardziej w kategoriach politycznych niż realnych efektów gospodarczych. 
Fakt pogarszającego się stanu gospodarki został niespodziewanie spotęgowany największym kryzysem ekonomicznym od lat 30. XX w., który został wywołany epidemią wirusa COVID-19. Kryzys ten według Międzynarodowego Funduszu Walutowego ma spowodować największą recesję od czasów Wielkiego Kryzysu sprzed 90 lat, znacznie poważniejszą w skutkach niż kryzys finansowy z 2008 r. ${ }^{55}$ Będzie on wymagał ogromnych nakładów na ochronę społeczeństwa i ratunek przedsiębiorstw, co niewątpliwie spowoduje uzasadnione przesunięcie priorytetów dla rządu. $\mathrm{Na}$ horyzoncie widnieją również strukturalne problemy kraju, jak np. katastrofalna sytuacja demograficzna. Niespotykana dotąd skala środków, jakie musiała podjąć większość gospodarek światowych, by chronić zdrowie i życie swoich obywateli, oznaczała też ogromne straty ekonomiczne i zmianę dotychczasowych prognoz dotyczących wzrostu gospodarczego w najbliższej przyszłości.

Zmiana paradygmatów dla krajów to również faktyczne zrewidowanie większości celów abenomiki. W dalszym ciągu spadający popyt, niepewność co do warunków uprawiania biznesu oraz znaczne ograniczenie wymiany handlowej niewatpliwie wpłynęły negatywnie na stan gospodarki, tym bardziej że Japonia jest jednym z państw najbardziej uzależnionych od dostaw produktów spożywczych. Kraj nie mógł w zaplanowanym czasie skorzystać gospodarczo na organizacji igrzysk olimpijskich, które zostały przełożone na rok 2021. Jest to o tyle istotne, że olimpiada miała funkcjonować jako nieoficjalna czwarta „strzała” pierwszej wersji abenomiki i koło zamachowe dla gospodarki, generujące przynajmniej dodatkowe 0,3\% PKB dla kraju ${ }^{56}$. Japonii grozi ponadto powrót do deflacji oraz recesji na poziomie tych z początku lat 90. MFW oceniało skalę spadku PKB kraju na 5,2\% w roku 2020 (najwięcej od roku 2009) ${ }^{57}$. Jeszcze przed wybuchem epidemii, w wyniku drugiej podwyżki podatku konsumpcyjnego, konsumpcja i wzrost gospodarczy w grudniu 2019 r. zaczęły znowu spadać. Z tego powodu, spotęgowanego nowym kryzysem, stopa inflacji spadła do poziomu 0,6\% w lutym $2020 \mathrm{r} .{ }^{58} \mathrm{~W}$ związku z ogłoszeniem koniecznego w kryzysowej sytuacji pakietu stymulującego gospodarkę na kwotę ponad 1 bln USD ${ }^{59}$ również plan konsolidacji fiskalnej musiał zostać odłożony w czasie, co unaoczniało wagę kryzysu.

55 MFW, World Economic Outlook. The Great Lockdown, Washington 2020, s. 5, https://www.imf. org/ /media/Files/Publications/WEO/2020/April/English/text.ashx?la=en (dostęp: 20.04.2020).

56 A. Fensom, 2020 Obmpics: A Fourth Arrow for Abenomics?, „The Diplomat”, 10.09.2013, https:// thediplomat.com/2013/09/2020-olympics-a-fourth-arrow-for-abenomics/ (dostęp: 4.07.2021).

57 Ibidem, s. 9.

58 J. Kyodo, Japan inflation rate slowed to 0.6\% in February as virus shock spread, „The Japan Times”, 19.03.2020, https://www.japantimes.co.jp/news/2020/03/19/business/economy-business/japaninflation-rate-slowed-february-coronavirus/\#.Xpw0B5ngrIW (dostęp: 20.04.2020).

59 J. Kyodo, COVID-19 stimulus response to boost Japan's GDP by up to 3.8\%, Abe says, "The Japan Times", 16.04.2020, https://www.japantimes.co.jp/news/2020/04/16/business/economy-business/coronavirus-stimulus-gdp/\#.Xp2rn5ngol0 (dostęp: 20.04.2020). 
Premier Shinzo Abe nie będzie jednak z tymi problemami się już mierzyć, ponieważ zrezygnował ze swojej funkcji z powodów zdrowotnych w sierpniu 2020 r., zaledwie cztery dni po tym, jak stał się najdłużej urzędującym premierem w historii Japonii ${ }^{60}$. Jego program abenomiki, jednej z największych politycznych ambicji polityka, ale też plan, który odbił się głośnym echem na całym świecie, nie spełnił pokładanych w nim nadziei i prawdopodobnie będzie wymagać gruntownej redefinicji po opanowaniu trwającej epidemii. Mimo to w aspekcie samego wyjścia z długotrwałej deflacji i m.in. znacznego pogłębienia współpracy międzynarodowej zauważalne są pewne sukcesy. W celu trwałego powrotu na ścieżkę wzrostu gospodarczego i odbudowania pozycji kraju potrzeba będzie jednak innych środków niż te, które wprowadzano w okresie 2012-2020.

\section{Literatura}

Aramaki K., Japan's Long Stagnation, Deflation, and Abenomics: Mechanisms and Lessons, Singapore 2018.

Armstrong S.P., The politics of Japan-China trade and the role of the world trade system, „World Economy" 2012, vol. 35, no. 9 .

Botman D., Danninger S., Schiff J., Can Abenomics Succeed? Overcoming the Legacy of Japan's Lost Decades, Washington 2015.

Craig M., The Abe Restoration: Contemporary Japanese Politics and Reformation, Lanham 2016.

Debate Surrounding the „New Three Arrows” of Abenomics, „Foreign Press Center Japan”, 12.08.2015, https://fpcj.jp/en/j_views-en/magazine_articles-en/p=38092/ (dostęp: 8.04.2020).

Fensom A., 2020 Olympics: A Fourth Arrow for Abenomics?, „The Diplomat, 10.09.2013, https://thediplomat.com/2013/09/2020-olympics-a-fourth-arrow-for-abenomics/ (dostęp: 4.07.2021).

Grabowiecki J., Dabrowski M., Abenomics and its impact on the economy of Japan, „Optimum. Studia Ekonomiczne" 2017, nr 5(89).

Hayakawa H., Reading Between the Lines of Abenomics 2.0, Nippon.com, 16.12.2015, https://www. nippon.com/en/currents/d00207/reading-between-the-lines-of-abenomics-2-0.html (dostęp: 8.04.2020).

Heazle M., Abe's domestic failings may cost Japan and the region-dearly, The Strategist, https://www. aspistrategist.org.au/abes-domestic-failings-may-cost-japan-and-the-region-dearly/ (dostęp: 14.06.2020).

Japan consumer spending, https://tradingeconomics.com/japan/consumer-spending (dostęp: 15.05.2020). Krugman P., Japan's Trap, May 1998, https://web.mit.edu/krugman/www/japtrap.html (dostęp: 21.03.2020).

Kyodo J., COVID-19 stimulus response to boost Japan's GDP by up to 3.8\%, Abe says, „The Japan Times”, 16.04.2020, https://www.japantimes.co.jp/news/2020/04/16/business/economy-business/ coronavirus-stimulus-gdp/\#.Xp2rn5ngol0 (dostęp: 20.04.2020).

${ }^{60}$ M. Rich, Shinzo Abe, Japan's Longest-Serving Prime Minister, Resigns Because of Illness, „The New York Times", https://www.nytimes.com/2020/08/28/world/asia/shinzo-abe-resign-japan.html (dostęp: 14.02.2021). 
Kyodo J., Japan inflation rate slowed to $0.6 \%$ in February as virus shock spread, „The Japan Times”, 19.03.2020, https://www.japantimes.co.jp/news/2020/03/19/business/economy-business/ japan-inflation-rate-slowed-february-coronavirus/\#.Xpw0B5ngrIW (dostęp: 20.04.2020).

Lechevalier S., Monfort B., Abenomics: Has it worked? Will it fail?, 13.12.2016, https://halshs.archives-ouvertes.fr/halshs-01415428 (dostęp: 21.03.2020).

Looming election returns Abe's focus to economy, Nikkei Asia, 25.09.2015, https://asia.nikkei.com/Politics-Economy/Policy-Politics/Looming-election-returns-Abe-s-focus-to-economy (dostęp: 11.04.2020).

MFW, General government gross debt, https://www.imf.org/external/datamapper/GGXWDG_ NGDP@WEO/OEMDC/ADVEC/WEOWORLD/JPN (dostęp: 29.03.2020).

MFW, The Great Lockdown, Washington 2020, https://www.imf.org/ /media/Files/Publications/WEO/2020/April/English/text.ashx?la=en (dostęp: 20.04.2020).

Ministerstwo Finansów Japonii, Japanese Public Finance Fact Sheet, Tokyo 2017, https://www.mof. go.jp/english/budget/budget/fy2017/04.pdf (dostęp: 19.04.2020).

Ministerstwo Finansów Japonii, Tax Reform (Main Points), FY2018, Tokyo 2017, https://www. mof.go.jp/english/tax_policy/tax_reform/fy2018/tax2018a.pdf (dostęp: 18.04.2020).

OECD, Average wages (indicator), 2020, doi: 10.1787/cc3e1387-en (dostęp: 19.04.2020).

OECD, Employment. Improving the labour market outcomes of women, Japan Policy Brief, April 2017, https://www/oecd.org/japan/japan-improving-the-labour-market-outcomes-of-women.pdf (dostęp: 31.03.2020).

OECD, Inflation (CPI) (indicator), 2019, doi: 10.1787/eee82e6e-en (dostęp: 17.04.2020).

OECD, Real GDP Forecast (indicator), 2020, doi: 10.1787/b86d1fc8-en (dostęp: 17.04.2020).

OECD, Unemployment rate (indicator), 2019, doi: 10.1787/997c8750-en (dostęp: 19.04.2020).

Przystup J., The Foreign Policy of Abe Shinzo: Strategic Vision and Policy Implementation, 5.02.2015, http://www.theasanforum.org/the-foreign-policy-of-abe-shinzo-strategic-vision-and-policy-implementation/ (dostęp: 21.03.2020).

Rich M., Shinzo Abe, Japan's Longest-Serving Prime Minister, Resigns Because of Illness, „The New York Times", https://www.nytimes.com/2020/08/28/world/asia/shinzo-abe-resign-japan.html (dostęp: 14.02.2021).

Schlesinger J.M., Nakamichi T., As Japan Battles Deflation, a Bitter Legacy Looms, „The Wall Street Journal", 11.06.2015, https://www.wsj.com/articles/as-japan-battles-deflation-a-bitter-legacy-looms-1434011826?tesla=y (dostęp: 22.03.2020).

Shibata S., Re-packaging old policies? 'Abenomics' and the lack of an alternative growth model for Japan's political economy, ,Japan Forum” 2017, vol. 29, no. 3.

Takenaka M., The ratio of regular workers is on the rise, „The Japan Times”, 28.11.2019, https://www. japantimes.co.jp/opinion/2019/11/28/commentary/japan-commentary/ratio-regular-workers-rise/\#.Xpw4tZngrIU (dostęp: 19.04.2020).

The 1930s and War Economy, https://www.grips.ac.jp/teacher/oono/hp/lecture_J/lec09.htm (dostęp: 22.03.2020).

Wakatsuki Y., Sbinzo Abe declares victory in Japan election butfails to win super majority, CNN, 22.07.2019, https://edition.cnn.com/2019/07/22/asia/japan-election-result-intl-hnk/index.html (dostęp: 17.04.2020).

Yamanaka M., List od Ambasadora Japonii w Polsce, 22.01.2013, https://jaap.pja.edu.pl/list-od-ambasadora-japonii-w-polsce/ (dostęp: 30.03.2020).

Yeo I., Debating Abenomics, „Seoul Journal of Japanese Studies” 2017, vol. 3, no. 1. 


\section{SUMMARY}

\section{THE ABENOMICS POLICY AS AN ANSWER TO JAPAN'S ECONOMIC PROBLEMS}

The aim of the article is to present the so-called Abenomics policy and its results with regards to the economic stagnation and chronic deflation which persisted in Japan since early 1990s. Created by the new Prime Minister of Japan Shinzo Abe and based on the reflationism theory, its goal was first and foremost to stop the deflation, but also reinvigorate demand and boost economic growth via means of structural reforms. These three objectives became known as the "three arrows" of the plan.

The core of the program focused on the quantitative easing policy (QQE) led by the Bank of Japan, which consisted of massive purchase of bonds which would in turn raise their prices and inject money into the economy. Other measures included setting the goal of reaching $2 \%$ inflation in two years' time, as well as enormous infrastructural investment and pension spending or numerous reforms regarding job market accessibility and deregulation. In the wake of the original plan's middling results the Abenomics 2.0 plan was presented in 2014 and focused on Japan's structural problems, which are rapidly aging population and shrinking workforce.

Critical examination showed that these new goals concerning projected GDP level or fertility rate were unrealistic from the onset and did not amount to much. Despite the country leaving the long-lasting deflation behind, it did not reach the set $2 \%$ inflation mark or GDP growth on the level of comparable economies.

Moreover, the debt level is still rising, partly because of the volume of the QQE policy. Adding to the situation is the recent economic crisis caused by the COVID-19 pandemic, which demanded a shift in government's focus and caused all of the economic indicators to again worsen. Despite some successes along the way, the main goals of the Abenomics were unfulfilled during Shinzo Abe's term of office, and Japan's economic problems remain to be solved by the next governments. 